\title{
THE EFFECTIVENESS OF NATIONAL COLLECTIVE MANAGEMENT ORGANIZATION REGULATION
}

\author{
Agus Sardjono, Brian A. Prastyo, and Derezka G. Larasati*
}

* Department of Civil Law, Faculty of Law Universitas Indonesia

\author{
Article Info \\ Received : 6 January 2016 | Received in revised form : 21 June 2016 | Accepted : 25 November 2016 \\ Corresponding author's e-mail : agussardjono@yahoo.co.id; prastyobrian@yahoo.com; larasati.desrezka@gmail.com
}

\begin{abstract}
Article 89 of Law Number 28 of 2014 provides for two National Collective Management Organizations (hereinafter briefly referred to as LMKN), both of which represent the interests of authors and owners of related rights. Both of said organizations possess the authority to impose, collect, and distribute royalties obtained from commercial users. The Minister of Law and Human Rights inaugurated commissioners assigned to said Authors' Rights LMKN and Related Rights LMKN. The LMKN is bound to have an operational effect on previously existing LMKs in Indonesia. Therefore, the objective of this study is to assess whether the existing LMKs feel that their needs are accommodated by the introduction of the LMKN. This research also aims to reveal the causing factors of the conflict which has been occurring between LMKs and Authors/Musicians/Singers, between LMKs, and between LMKs and Commercial Users of Songs/Music. This research also aims to elaborate on the existing regulation patterns concerning LMKs worldwide. The research will be conducted by using normative and empirical legal research method. Normative research will be conducted to examine the normative aspects of LMKs and LMKN. On the other hand, empirical research will be aimed at understanding and analyzing the outlook of actors, in particular LMKS existing prior to the 2014 Copyright Law coming into effect. This research is expected to come up with recommendations concerning the regulation of music/song LMKs in Indonesia in the future.
\end{abstract}

Keywords: LMK/LMKN, UUHC, Permenkumham, musical works, song

\begin{abstract}
Abstrak
Undang-undang Nomor 28 tahun 2014 tentang Hak Cipta dalam Pasal 89 memberikan dua Lembaga Manajemen Kolektif Nasional (selanjutnya disebut sebagai LMKN), yang merupakan perwakilan kepentingan dari pencipta dan pemilik hak cipta dari hak-hak terkait. Kedua lembaga tersebut memiliki kewenangan untuk menetapkan, memungkit, dan mendistribusikan royalti yang diperoleh dari pengguna komersial. Menteri Hukum dan HAM mengangkat komisioner LMKN Pencipta dan LMKN Hak Terkait di Indonesia. Sehingga, tujuan dari tulisan ini adalah untuk meninjau apakah LMKyang ada telah merasa bahwa kebutuhan LMK tersebut telah diakomodasi dengan pendirian LMKN. Selain itu juga, tulisan ini bertujuan untuk mengungkapkan faktor penyebab konflik yang tengah terjadi antara LMK dan Pencipta/Musisi/Penyanyi, antara LMK, dan antara LMK dan pengguna komersial dari lagu/musik. Tulisan ini juga bertujuan untuk menjabarkan ketentuan peraturan mengenai LMKyang ada di dunia. Tinjauan ini akan dilakukan dengan metode normatif dan empiris. Kajian normatif akan dilakukan untuk memeriksa aspek normatif dari LMK dan LMKN. Di sisi lain, kajian empiris ditujuan untuk memahami dan menganalisa pandangan dari para pelaku, khususnya LMK yang telah ada sebelum UU Hak Cipta 2014 berlaku. Kajian ini diharapkan dapat menghasilkan rekomendasi mengenai peraturan LMK musik/lagu di Indonesia di masa depan.
\end{abstract}

Kata kunci: LMK/LMKN, UU HC, Permenkumham, karya musik, lagu 


\section{INTRODUCTION}

Following the promulgation of Law No. 28 of 2014 concerning Copyright, on January 20th 2015, the Minister of Law and Human Rights inaugurated commissioners assigned to the LMKN (both at the Authors' LMKN as well as at the Related Rights LMKN). Prior to said inauguration, the Minister of Law and Human Rights had issued the Regulation of the Minister of Law and Human Rights No. 29 of 2014 concerning the Procedure for Application and Issuance of Operational License, and the Evaluation of the Collective Management Organization. Said Regulation of the Minister of Law and Human Rights (hereinafter briefly referred to as Permenkumham) provides for the LMKN's tasks, as follows:

a. formulate the code of ethics for LMKs in the area of songs and/or music;

b. conduct supervision of LMKs in the area of songs and/or music;

c. provide recommendations to the Minister for the imposition of sanction for violations of the code of ethics by LMK managements;

d. provide recommendations to the Minister related to the licensing of LMKs in the area of songs and/or music under their coordination;

e. stipulate the system and procedure for calculating royalty payments by users to LMKs;

f. stipulate the procedure for distributing royalty and the amount of royalty to the Author, Copyright Holder, and the owner of Related Right;

g. conduct mediation disputes involving Author's Rights and Related Rights; and

h. submit performance reports and financial reports to the Minister.

As media reports indicate, the introduction of the LMKN has raised high expectations. The Minister of Law and Human Rights of the Republic of Indonesia has stated that "it is expected that the existence of LMKN in the area of music will be able to bring the greatest possible benefit to authors, holders of author's rights and related rights," ${ }^{1}$ while the Director General of Intellectual Property rights stated that "state revenues from the music sector total to 5 trillion Rupiahs per year. Authors receive only a small portion of said amount. According to the Director General of IPR, the LMKN will help ensure that users pay royalty to holders of authors' right. If the LMKN is successful in collecting only 5 percent of the total revenues in the music industry, authors creating music will be able to live in prosperity." ${ }^{2}$ Adi Adrian, one of the LMKN commissioners, has stated that 'with the existence of LMKN, users' obligation to pay performing rights will be enforced more effectively. Businesses such as karaoke halls or restaurants will be obligated to pay royalites each time they play a song for commercial purposes. Such payment will then be made to the LMKN to be further conveyed to the songwriter concerned." ${ }^{3}$ Ebiet G Ade, another LMKN commissioner, has stated that "the presence of the LMKN will serve to reinforce the obligation of users of authors' rights such as karaoke halls, cafes, or restaurants playing songs for

1 Ministry of Law and Human Rights, "Menkumham Melantik Komisioner LMKN Pencipta dan Hak Terkait [Minister of Law inaugurates Authors and Related Rights LMKN Commissioners]," http://www. kemenkumham.go.id/v2/berita/330-menkumham-melantik-komisioner-lmkn-pencipta-dan-lkmn-hakterkait\#sthash.Sf9xa3w2.dpuf, accessed on 15 May 2016.

2 Tempo, "Potensi Kerugian Hak Cipta Rp 3 Triliun per Tahun [Potential losses of copyright Reach 3 trillion rupiah annualy]," http://www.tempo.co/read/news/2015/01/20/078636265/Potensi-KerugianHak-Cipta-Rp-3-Triliun-per-Tahun, accessed on 14 May 2016.

${ }^{3}$ Ibid. 
commercial purposes."4 Bens Leo, an observer of the music industry, has stated: "What needs to be done, in my view, is to solidify the existing organizations, in order to ensure that the collecting of royalties by them is effected in a more transparent and non-conflicting manner. Let us take for example Inul Daratista; we can only imagine she owns more than 80 karaoke halls in Indonesia. Regardless of whether or not she is partnering with other parties, Inul has been certainly making a lot of money from the karaoke business. However, she must also pay royalties to several parties whose songs are being used there."5

By taking a closer look at said phenomenon, it becomes evident that prior to the introduction of the LMKN, there was not much media coverage of the opinion of LMK management circles. Up to 2013, there were at least 6 (six) LMKs in the music industry operating in Indonesia, namely KCI (Karya Cipta Indonesia), RMI (Royalti Musik Indonesia), WAMI (Wahana Musik Indonesia, ASIRI (Asosiasi Industri Rekaman Indonesia), ASPRINDO (Asosiasi Penata Rekam Indonesia), dan PRISINDO (Performers' Rights Society of Indonesia). ${ }^{6}$

The presence of several LMKN commissioners with the track record of having served on the management of LMKs in the past does not provide sufficient ground to conclude that the LMKs had given their support to the establishment of the LMKN. Therefore, the potential non-effectiveness of copyright law requires serious anticipation, bearing in mind the fact that the issues related to song/music royalty collection has been going on for a rather long period of time.

One of the issues relating to the collection of song/music royalties has been the dissatisfaction of authors/musicians/singers in view of proceeds from royalty collection by LMKs. For example, famous singer Rhoma Irama founded RAI in 2013 due to his dissatisfaction with KCI, arguing that "we have left Karya Cipta Indonesia (KCI) because dangdut composers have not been treated well by KCI. We have disassociated ourselves from KCI in order to found RAI specifically for dangdut music... Now, Indonesian dangdut music belongs to RAI. All dangdut music composers will register their work at RAI. Prior to that, dangdut music users used to pay royalty to $\mathrm{KCI}^{\prime}{ }^{7}$

Another problem related to the operational aspects of LMKs is the calculation of royalties to be paid by users. This is evident, for instance, from the release of the refusal of the management of the Indonesia Hotel and Restaurant Association to accept royalty collection by KCI. ${ }^{8}$ On July 10, $2006 \mathrm{KCI}$ also received an open summons through Kompas daily newspaper by the Indonesian Record Industry Association (ASIRI), as ASIRI was questioning KCI's authority to collect royalties. As records

${ }^{4}$ Varia.id, "LMKN Ingin Amankan Rp. 3 Triliun Royalti Lagu [LMKN wants to secure 3 trillion rupiah worth of music royalty," http://www.varia.id/2015/01/21/lmkn-ingin-amankan-rp-3-triliun-royaltilagu/\#ixzz3TL6Ps05n, accessed on 14 April 2016.

5 Vitri Angreni, "Bens Leo: Bens Leo: Tugas LMKN Jangan Tumpang Tindih Dengan Lembaga Serupa [Bens Leo: Tasks of LMKN must not overlap with similar institutions]," http://www.portalkbr.com/berita/ perbincangan/3380210_5534.html, accessed 10 May 2016.

${ }^{6}$ HukumOnline, "Pro Kontra Eksistensi Lembaga Manajemen Kolektif [Pros and Cons of the Existence of Collective Management Organization]," http://www.hukumonline.com/berita/baca/lt517fd780019e8/ pro-kontra-eksistensi-lembaga-manajemen-kolektif, accessed on 15 May 2016.

7 DetikHot, "Rhoma Irama: Artis Dangdut Keluar Dari KCI [Rhoma Irama: Dangdut musicians exit KCI]," http://hot.detik.com/music/read/2013/03/28/113828/2206000/228/rhoma-irama-artis-dangdutkeluar-dari-kci, accessed on 15 May 2016.

${ }^{8}$ Joglosemar, "PHRI Solo Tolak Bayar Royalti KCI [Solo branch of Indonesian Association of Hotel and Restaurant refuse ot pay royalty for KCI]," http://www.edisicetak.joglosemar.co/node/20653, accessed on 16 May 2016. 
indicate, the same debate had occurred between ASIRI and KCI in 2006, each of them claiming to have the strongest authority to collect royalties on songs/music. ${ }^{9}$

LMKs have also been frequently in conflict with song users. Take for instance the conflict between KCI and Inul Daratista. Inul, as the owner of karaoke parlors, has held the view that the substance of agreement between KCI and karaoke business actors is not clear and it poses a burden on business actors. Inul has made the following statement, "The agreement is general in nature, because unlike similar organizations overseas, KCI does not possess a system which provides accurate data on the songs played every day. The discussion on royalty in proceedings between KCI and song writers should not be general in nature. They should possess data which should be able to control that."10

After taking a careful look at various records of conflicts between LMKs and authors/musicians/singers, between LMKs, between LMKs and users of music/ songs, the need for a thorough study of the role of LMKs becomes quite evident. Based on said records, there is a strong reason to believe that there is certain dissatisfaction with the appointment of certain commissioners who have been in conflict with existing LMKs. Similarly, by looking at the background of the founding of RAI in the past can also raise an important issue: if the purported background of the founding of RAI is correct, each music genre would be able to claim the founding of its own LMK in the future. In other words, separate LMKs for Rock, Jazz, Keroncong and other music genre song writers may very well be founded in the future, which could create a nonconducive ambiance in the music industry.

Money is undoubtedly the most attractive aspect of collecting royalties. However, who is that money for? Is it correct to state that the collection of royalties has resulted in adequate income for song/music writers or has it only created prosperity for LMK managers? Would the LMKN be able to resolve the various issues of the past which have created an ongoing conflict for LMKs? All of these are important issues that need to be elaborated upon, because the trust of the community-particularly authors and artists in the area of music - towards LMKs needs to be developed. The LMK cannot be expected to develop without the community's trust.

Based on the foregoing, there is a need to conduct research concerning the existence of the LMKN. The research is expected to indicate clearly whether the existing LMKs view favorably the existence of LMKN. The research is also expected to reveal the causing factors of conflict occurring between LMK and Authors/Musicians/ Singers, between LMKs, and between LMK and Commercial Users of Songs/Music. The research will also show the patterns of LMK regulation worldwide. The various findings of the research will be useful input for the formulation of recommendations concerning the regulation model for music/song LMKs in Indonesia in the future.

Based on the above described background, the following issues will be the subject of research:

a. Are existing LMKs satisfied with the LMKN regulation and the composition of LMKN personnel?

\footnotetext{
${ }^{9}$ HukumOnline, “Memungut Royalti Lagu, Hak Siapa? [Levying Music Royalty, Whose Right?],” http:// www.hukumonline.com/berita/baca/hol15903/memungut-royalti-lagu-hak-siapa, accessed on 13 May 2016.

${ }_{10}$ Majalah Internet, "Inul Daratista Minta Revisi UU Hak Cipta [Inul Daratista Request Copyright Law Revision]," http://www.majalahinternet.com/2013/04/inul-daratista-minta-revisi-uu-hak-cipta.html, accessed on 13 May 2016.
} 
b. Does the regulation on the LMKN and its relationship with LMKs share any similarities with regulations in other countries?

c. Is it going to be easy for the LMKN to implement the rules concerning governance of royalty collection, stipulation and distribution?

d. What would be the most adequate LMKN and LMK regulation in Indonesia?

\section{REGULATIONS OF LMK IN INDONESIA}

\section{A. Definition and Role of LMK}

An LMK is a type of organization that is commonly known for representing authors, copyright owners, and/or related rights owners in collecting and distributing royalties obtained from commercial users. The history of LMK started in France, when Pierre-Augustin Caron de Beaumarchais with 22 renowned French drama writers in the 1700s founded the French Society of Drama Authors. ${ }^{11}$ Initially, the LMK was regarded as an efficient way of collecting and distributing royalties. However, as Daniel Gervais has stated, the LMK structure of modern times, both on a national as well as international level, indicates that the efficiency principle needs to be re-examined. ${ }^{12}$

Copyright Law 19/2002 (UUHC 2002) does not provide the definition of LMK; the only term used which may have the closest meaning to the common definition of LMK is 'professional organization' which is referred to in Article 45 (4) related to payments of royalties for the licensing of copyrighted works. However, the term 'professional organization' does not always mean LMK. ${ }^{13}$ In the new Copyright Law 28/2014 (UUHC 2014), an LMK is defined as an organization in the form of non-profit legal entity granted authority by the Author ${ }^{14}$, the Copyright Holder ${ }^{15}$, and/or the holder of Related Right16 to manage its economic rights in the form of collecting and distributing royalty.

In Article 87 of the UUHC 2014, authors, copyright owners, and related rights owners are encouraged to become members of an LMK, so that the institution may act as their representative to collect royalties from commercial users. On the other side, commercial users are also told to pay royalties to the LMK based on the licensing contract that they made with said LMK.

11 Daniel Gervais, Collective Management of Copyrights and Related Rights (the Netherlands:Wolters Kluwer International, 2015), p. 4.

12 Ibid., p.5.

13 In practice, several LMKs have already been formed for the purpose of collecting royalty and managing the economic rights of Authors/Copyright Holders. Some of these LMKs include YKCI (Yayasan Karya Cipta Indonesia), Royalti Anugerah Indonesia (RAI), Wahana Musik Indonesia (WAMI), ASIRINDO (Asosiasi Industri Rekaman Indonesia), and PRISINDO (Performers' Rights Society of Indonesia). As an example of a professional organization that does not act as LMK is PAPPRI (Persatuan Artis Penyanyi, Pencipta Lagu, dan Pemusik Republik Indonesia - Association of Singers, Composers, and Musicians of the Republic of Indonesia). However PAPPRI has recently also set up a special LMK, namely LMK PAPPRI. (http://www.pappri.com/about-us/).

14 Author is a person or several persons who individually or collectively produce a work which is unique and individual in nature; Indonesia, Undang-Undang tentang Hak Cipta (Law concerning Copyright), UU No. 28 tahun 2014, LN. No. 266 tahun 2014 (Law No. 28 of 2014, SG No. 266 of 2014), Article 1 number 2 .

15 Ibid.

${ }^{16}$ Ibid., Article 1 number 4 


\section{B. The Difference Between LMK and LMKn}

The main difference between an LMK and the LMKn is that an LMK is formed by the society while the LMKn is formed by the government. While an LMK can be formed in all fields of copyrighted works, the LMKn only operates in the field of copyrighted song/musical works.

According to Article 88 of the UUHC 2014, an LMK in song/musical works can be formed if it has at least 200 authors listed as members or at least 50 related rights owners. All LMK members must give a letter of power of attorney to their LMK, so that their LMK can collect and distribute royalties for them. An LMK can spend a maximum of $20 \%$ out of their total annual royalty revenues for operational purposes and all financial and management performance must be audited by a public accountant at least once a year. The government will evaluate the LMK's performance annually. In order to perform its role, an LMK must obtain operational license from the government. It would constitute as a criminal action if an LMK collects royalties without having obtained an operational license from the government.

According to Article 89 of the UUHC 2014, there are two kinds of LMKn: LMKn for Authors and LMKn for Related Rights Owners. The law stated that the LMKn has the authority to collect and distribute royalties from commercial users. However, the law does not oblige the LMKn to have a letter of power of attorney from the authors or related rights owners. The law also does not oblige the LMKn to issue a licensing contract to the commercial users as the legal basis to collect royalties from them. There are also no rules regarding the amount of annual royalty revenues that can be used for operational purposes, no duty to audit the financial and management performance, and no annual government's evaluation applied. The law only obliges those two LMKn to coordinate for the purpose of setting up royalty tariff.

\section{Establishment of LMKN ${ }^{17}$}

Minister of Law and Human Rights Regulation No. 29 Year 2014 concerning the Procedure for Application and Issuance of Operational License and Evaluation of Collective Management Organization (hereinafter briefly referred to as Permenkumham 29/2014) stated that the LMKN for Authors is composed of persons whom are representing LMKs, authors, academicians, and legal experts in the field of copyright. While the LMKN for Related Rights Owners is composed of persons whom are representing LMKs, related rights owners, academicians, and legal experts in the field of copyright. Furthermore, both LMKNs can delegate their respective authority to collect and distribute royalties from commercial users ${ }^{18}$ to LMKs of similar type under their coordination.

Following are the particular tasks of the authors' LMKN and related rights LMKN

17 Minister of Law and Human Rights Regulation No. 29 of 2014 (Permenkumham 29/2014) uses the term LMKN (with a capital N). This is slightly different from the provisions in UUHC 2014, which uses the term LMKn (with a small n), implying that the LMKn is also LMK, however, as this organization is an organization formed by LMKs, the LMKn has a national character. Indeed, this is only a different way of interpretation compared to the interpretation by the Minister of Law and Human Rights. It is, therefore, still debatable.

${ }^{18}$ Seen from the legal doctrinal point of view, such delegation is still debatable bearing in mind that the LMKN does not in fact have the right to collect royalty from users, unless powers or substitution powers are granted by right holders, namely the Author, Performing Artist and Producer concerned. 
respectively ${ }^{19}$ :

a. formulate the code of ethics of LMKs in the area of songs and/or musical works;

b. conduct supervision of LMKs in the area of songs and/or musical works;

c. provide recommendations to the Minister of Law and Human Rights in imposing sanctions for violations of code of ethics by LMK managers;

d. provide recommendations to the Minister of Law and Human Rights related to the licensing of LMK in the area of songs and/or music under his/her coordination;

e. stipulate the system and procedure for calculating Royalty payment by users to LMKs;

f. stipulate the procedure for the distribution of Royalties and the amount of royalty for Authors, Copyright Holders, and owners of Related Rights;

g. conduct mediation in Copyright and Related Rights disputes; and

h. submit performance reports and financial reports to the Minister of Law and Human Rights.

In implementing its described tasks above, the Authors' LMKN and Related Rights LMKN are led by independent Commissioners, with an uneven number of Commissioners consisting of up to 5 (five) persons. ${ }^{20}$ For the first time, LMKN Commissioners are selected by an independent selection committee formed and stipulated by the Minister of Law and Human Rights. The election of next Commissioners is to be subsequently implemented by an independent selection committee formed and stipulated by the current Commissioners. ${ }^{21}$

\section{REGULATIONS FOR LMK IN OTHER COUNTRIES}

In the United States, there are at least three types of LMKs, namely Copyright Collective, Collecting Society, and Sound Exchange. The Copyright Collective engages in the field of music, while the Collecting Society operates in the field of written works, and the Sound Exchange engages in music works in the digital world. Only the Sound Exchange is regulated directly by the state, while other LMKs are selfregulatory bodies. Complaints by commercial users are settled in court, or each of the parties concerned take their own initiative to settle the dispute. The U.S. Government has not formed a special organization to settle disputes between copyright collective or collecting society with commercial users. However, for Sound Exchange, the government has formed and has provided specifically, and it has formed an organ

${ }^{19}$ Minister of Law and Human Rights of Republic Indonesia, Peraturan tentang Tata Cara Permohonan dan PenerbitanIzin Operasional serta Evaluasi Lembaga Manajemen Kolektif [Regulation concerning the Application Procedure and Issuance of Operational Permint as well as the Evaluation of Collective Management Organization], Peraturan Nomor 29 tahun 2014 (Regulation No. 29 of 2014), Article 6.

20 Limiting the number of LMKN members also raises the issue of consistency with provisions concerning the representation of elements of LMK and right owners. It would be far more appropriate if the number of members was not limited to 5 , rather, if it would be limited by the total number of existing LMKs, with each LMK being allowed to be represented by their representatives in the LMKN's organization, in addition to copyright experts and experts in the music industry.

21 Please refer to Articles 6, 7, and 8 of the Regulation of the Minister of Law and Human Rights No. 29 of 2014 concerning the Application Procedure and Issuance of Operational Permit and Evaluation of Collective Management Organization. 
referred to as Copyright Royalty Judges for stipulating royalty tariffs, conducting supervision, and for determining whether or not a violation has occurred.

In the European Union, there is no specific LMK regulation. European Union authorities view LMKs as part of the private sector in the economic area, with their conduct subject to business competition related rules. Therefore, in the event of complaints or reports of losses by commercial users, business competition articles can be applied to LMKs.

In the two countries above mentioned, the organization of LMKN is not recognized. In addition to that, none of the above mentioned countries apply regulations concerning operating licenses for LMKs and the maximum amount of collected royalty funds which may be used. There are no criminal provisions either specifically provided for LMK. For a better understanding of the difference between the system in Indonesia and the United States of America and the European Union respectively, please refer to the table in the attachment hereto.

In Japan, there is an organization referred to as Japanese Society for Rights of Authors, Composers, and Publishers, or JASRAC, which was established in 1939. JASRAC used to be the only organization managing royalty for the use of works of music in Japan. However, by issuing the regulation on Business Management for Copyright and Neighboring Rights, the opportunity was opened up for the establishment of other organizations for the collection and distribution of royalties to right holders. Thus, authors or owners of related rights are able to select and determine the rights for which they choose to authorize JASRAC, and the rights for which they wish to authorize other organizations or which they wish to manage by themselves, for instance the right on the use of works in the Internet network.

The JASRAC management system involves the consensus of its members participating in the organizational structure of JASRAC. Authors and/or Related Right Owners meeting requirements as JASRAC members and who have signed a contract with JASRAC for the management of their royalty are able to participate in the management of the organization as 'associate members.' Following a three-year period, associate members meeting certain requirements can become full members. For the purpose of making decisions concerning important operational or administrative matters, such as JASRAC's management policy, general meetings are convened, which serves as a forum for its full members to express their opinion. In addition to that, meetings of the board of directors are also held. Day-to-day operational matters ranging from the issuance of license to the distribution of royalties are implemented by the president of the JASRAC, the executive director, and other staff members working at the JASRAC's head office or regional offices.

The JASRAC's operational expenses are covered from the administration fee charged in the process of collecting royalties from users, or sent by the collective management organizations in other countries. In the event that revenues from said administration fee exceed the operational expenses, the surplus is returned to the right holders concerned ${ }^{22}$.

In the international sphere, CISAC or International Confederation of Societies of Authors and Composers, is a confederation of worldwide LMKs that operates in the international level. The CISAC was founded in 1926, and it is a non-profit, non-

${ }^{22}$ JASRAC, "Entrustment of Copyright to JASRAC," http://www.jasrac.or.jp/ejhp/about/admini_env. html, accessed on 14 May 2016. 
government organization. There is no international treaty that is made to govern the operation of the CISAC.

The CISAC headquarters are located in France, with regional branch offices located in Burkina Faso, Africa; Chile, South America; the People's Republic of China for the Asia Pacific Region; and Hungary in Europe. The CISAC has 230 LMK members in 120 countries, and it represents at least 3 million authors from various parts of the world for artistic works, music, audio-visual works, drama, literary works and visual works. The main task of the CISAC is to protect the rights and interests of authors worldwide, including but not limited to ensuring royalty payments to authors whose works are being used. ${ }^{23}$

\section{OPINIONS OF LMK REGARDING THE ESTABLISHMENT AND THE ROLE OF LMKN $^{24}$}

Opinions gathered from the focus group discussions held for this study show that the establishment of the LMKN has yet to fully meet expectations of all the LMKs. LMKs feel they have not been sufficiently involved in the establishment of the LMKN. Furthermore, they also think that the government has made incorrect interpretation on the meaning of the term "representation" in the definition of LMKN as stated in Permenkumham 29/2014. For the LMKs, the term "representation" should be interpreted as a person assigned by each of the LMKs to be seated in the LMKN's body. The reality that all commissioners of the LMKN were appointed by the government is disappointing for them.

Some LMKs view that the LMKN should not be formed by the government. According to them, the LMKN should be an association or a federation of similar independent LMKs. They believe this association or federation type of organization is suitable for them to perform their roles as royalty collecting and distributing organization. The purpose of this would be to avoid double collecting or the collection of royalty from 1 (one) user by multiple LMKs repeatedly. Through the association/ federation type of the LMKN, it is expected that it would be sufficient for users to pay royalties to one particular LMKN. This is also in line with the authority set out in the UUHC, specifically that the LMKN is entitled to collect and distribute royalties through coordination with LMKs.

The LMKs also seem to have yet to understand why they are not being involved by the government in the determination of the system for royalty collection and distribution. They believe that they should have been involved, because they are the persons who have had the experiences and vast knowledge about how the music industry works.

They also show dissatisfaction regarding the selection and appointment of LMKN's commissioners, because the government did not collaborate with them. The LMKs expect that they would be involved in the appointment of commissioner members. They believe the commissioners' selection through an open candidate registration system is flawed, because the elected commissioners do not show adequate experience for implementing and managing the collection and distribution of royalties compared

${ }^{23}$ CISAC, “CISAC: Who We Are," retrieved from www.cisac.org/Who-We-Are, accessed 14 May 2016.

24 The FGD (Focus Group Discussion) was held at the Faculty of Law Universitas Indonesia on June 8, 2015 attended by representatives of ASPERINDO, ASIRINDO, PRISINDO, APMINDO, NAF, APERKI, HAPPY PUPPY, and PAPPRI. 
to the currently existing LMKs.

One of the examples that justify their view about the incompetency of the LMKN commissioners is related to the enactment of tariff for family karaoke establishments. The LMKN commissioners have set the royalty tariff for family karaoke at Rp 12,000; divided into two, Rp 6,000 to the Author, and $\mathrm{Rp} \mathrm{6,000} \mathrm{to} \mathrm{the} \mathrm{Related} \mathrm{Right} \mathrm{Owner;}$ per room per day. According to some LMKs, the problems with this system are:

a. even though users are ready and committed to pay the royalty tariffs determined, paying the royalties does not necessarily release them from the risk of claim by the Author or Related Rights Owner concerned; hence, there remains the risk of claim for double royalty (double collecting) faced by users;

b. such double collecting can also originate from LMKs, with several LMKs collecting royalties from users, especially with the decision on the "delegation" of authority from the LMKN to more than one LMKs to collect royalties; and

c. in connection with items a and b above, the blanket license system is yet to equitably fulfill the royalty rights of right holders, unless royalty is actually distributed in accordance with the total use or playing of songs at users' venue (family karaoke). In reality, distribution does not always reach the right recipient due to the lack of data/information available from LMKs regarding users about the specific songs played, and the total number of times played at the karaoke parlor. This dilemma can be overcome by users providing a list to the LMK of the songs used. The absence of a list of the songs/music used may potentially lead to disputes in collecting and distributing royalties. Under such circumstances, right holders may claim royalty directly from users even though users have already paid so, because the right holders concerned may not have received such payment, or because they may not have authorized the LMK receiving payment from users to collect royalties;

d. in order to overcome said issue, the option of collecting royalties based on the pay-per-use system has emerged, namely the system of collecting and distributing royalties based on actual data on songs played and the total number of such songs having been played. However, users have yet to fully support the said option, as the implementation of the pay-per-use option requires additional investment for installing equipment on the system playing karaoke songs enabling to record and save data on the songs played and the number of times played. In other words, there is a need for further consensus between LMKs and users concerning the mechanism and sharing the burden of investment for the installation of such equipment.

Apart from the above mentioned issue of royalties and collecting system, there are also certain differences of opinions between LMKs and commercial users related to the payment of royalties for related rights owners, in particular the right of producers of phonograms. Producers feel they also have the right to royalty as karaoke businesses make such songs available through equipment installed at karaoke parlors.

In the discussions with users, it has also emerged that users, in particular karaoke businesses, are admittedly committed and possess the good faith to pay royalties to right holders at the determined rate of Rp12,000. However, they wish to have legal certainty concerning the party to which they have to deposit payment 
of such royalties, ${ }^{25}$ as mandated in the new Copyright Law. They also wish to have legal certainty against claims/double claims from right holders, after they pay the determined royalty.

\section{ANALYSIS}

\section{A. LMKN As the Collector and Distributor of Royalty}

The authority of the LMKN to collect and distribute royalties should be questionable. The power to collect royalty must be based on the permissions from the author, copyright owner, and/or related rights owner. The LMKN does not have those permissions, because those right holders are not members of the LMKN.

Under the current conditions, powers are obtained from existing LMKs from right holders. A potential solution to overcome the issue stated above would be granting authority with the right of substitution by LMKs to the LMKN.

The idea above would easily be implementable if the position of the LMKN itself was clear, namely that: (a) the LMKN is an LMK formed in the same manner as an LMK as provided for in UUHC 2014; (b) the LMKN is also a non-profit legal entity which can be in the form of a federation of existing LMKs which already hold powers. Furthermore, such LMKs have distributed their powers to the LMKN, enabling the LMKN to implement its authority to collect and distribute royalties to right holders. Unless the LMKN has mandate or receives powers of substitution from the LMKs concerned, it does not have the legal standing to represent authors, or artists/ performers, or producers ${ }^{26}$.

The formation of LMKN as a federation or association of LMKs can also serve as a solution to avoid conflict of interests in collecting and distributing royalties by LMKs and the LMKN respectively. The LMKN's position as a federation of LMKs would help create legal certainty that collecting and distribution by the LMKN and its member LMKs are one and the same, that it is harmonized; hence, double collecting from users could be avoided. By specifically stating in the substitution powers that "once an LMK substitutes its powers to the LMKN, it is no longer allowed to collect royalties from users" would make it even more clear cut.

\section{B. LMKN As the Regulator of LMK}

As the regulator which has the task and authority to stipulate the system for collecting and distributing royalties, including the code of ethics and other policies related to the technical aspects of LMK, commissioners at the forefront of the LMKN need to be selected from professionals who understand the various aspects of LMK and of collecting and distributing royalties. This is true regardless of whether

25 The above statement was made in the FGD. In view of the rapid developments taking place, the statement may no longer be relevant at the time of writing this report. However, double collecting may still occur when the LMKN delegates its collecting authority to the LMKs in accordance with the authority granted based on the above mentioned Regulation of the Minister of Law and Human Rights.

${ }^{26}$ Bearing in mind that the basis of the LMK's authority to collect royalty from users is the power of attorney from the author and/or owner of related right concerned, there is a need for substitution powers from the LMK to the LMKN, hence the LMKN would have the powers to represent authors and related right owners through the respective LMKs. Refer to Agus Sardjono, "Problem Hukum Undang-Undang Hak Cipta 2014 dalam Pengaturan LMK dan LMKN [Issues of Law Related to the 2014 Copyright Law in Regulating LMK \& LMKN]", (paper presented in the seminar organized by PAPPRI, on November 25, 2014). 
the LMKN is formed by the government, or as a federation or association of LMKs receiving mandate from the government to issue royalty related policy.

Under the current conditions, in the absence of power from right holders to the LMKN to collect royalties, it is more relevant for the LMKN to act as the regulator, notwithstanding the doctrinal issue described above. Regardless of the matter, in order to ensure that the royalty related policy or provisions such as tariff, system for collecting, distribution policy, code of ethics, and other matters that would be able to

a. meet the expectations of LMKs and users; and

b. overcome the ongoing problems related to collecting and distributing royalties

LMK representatives, right holders and users should also be involved in the process of formulating such policy as parties directly affected by the product of such policy for collecting and distributing royalties.

Commissioners must possess the ability to formulate policy or regulations capable of overcoming current ongoing issues related to collecting and distributing royalties, such as:

a. double collecting;

b. the distribution of royalties not reaching the intended target; and

c. the lack of transparency and fairness in collecting royalties based on the blanket license system, as well as the creation of a streamlined, efficient and effective system for collecting and distributing royalty for LMKs as well users.

Accordingly, there is a need for professional commissioner members possessing the relevant competence, who understand the various aspects of collecting royalty and the copyright related business.

As the current LMKN members havealready been elected by the Selection Committee formed by the Government, it needs to be ensured that at least the selection of future members of the LMKN is conducted based on the system of LMK representation in the LMKN. In other words, members of the LMKN must be representatives of LMKs who are members of the LMKN concerned. It will be elaborated upon further in the section below.

\section{The Form and Composition of LMKN}

The new Copyright Law and Permenkumham 29/2014 provide for the form of LMK, namely as a non-profit legal entity. At the same time, there are no provisions concerning the form of the LMKN's body or organization. There is only a general provision in Permenkumham 29/2914 that the LMKN is also an LMK which represents the elements of LMK, authors'/related rights owners, academicians and legal experts in the area of copyright for the purpose of managing the economic rights of author's/ related rights owners in the area of songs and/or music. Based on said provision, it can be concluded that the LMKN has the following characteristics:

a. the LMKN is also an LMK; and

b. the LMKN's organizational form must represent elements of LMK, authors/ related right owners, academicians, and Copyright law experts.

It would appear that, in formulating requirements for LMKN Commissioners, the Minister of Law and Human Rights did not take sufficiently into account the difficulty 
in implementing such provisions. The key word in said article is "merepresentasikan" ("representing"). Referring to Kamus Besar Bahasa Indonesia, the meaning of the word "merepresentasikan" ("representing) is "mewakili" (representing) or "bertindak sebagai wakil (atas nama)" (acting as representative (on behalf of.). Accordingly, a person acting as "wakil" (representative) is not a person entirely acting at its own will; rather than that, it is a person implementing the will of the parties represented by it. According to the wording of said article, there are five parties which can send their representatives, namely LMKs, Authors, Related Right Owners, Academicians, and Legal Experts in the area of Copyright.

If the Minister of Law and Human Rights is consistent in applying the said article, the procedure for filling the membership of Commissioners should be conducted in the following manner:

a. first, the Minister of Law and Human Rights sends a letter to the entire population of the five elements of representatives mentioned above requesting the names of people who will be representing them in the LMKN;

b. second, the population of each of the representative elements mentioned above agree upon certain people who would represent them and submit the names of such persons to the Minister of Law and Human Rights; and

c. third, the Minister of Law and Human Rights ratifies said persons appointed as representatives as the LMKN Commissioners.

In reality, the procedure for filling LMKN Commissioners membership does not follow the order described above. LMKN Commissioners inaugurated by the Minister of Law and Human Rights on January $20^{\text {th }}, 2015$ had been selected by a Selection Committee formed by the Minister of Law and Human Rights. The Selection Committee made the selection from among persons who had registered as LMKN Commissioner Candidates, based on a publicly announced and unlimited registration system.

Based on said procedure implemented by the Minister of Law and Human Rights, every person registering as the LMKN Commissioner Candidate in fact represents itself. They may as well possess professional or organizational background in at least one of the five representation elements; however, they are not appointed by the population in each of the respective representation elements to represent them. Consequently, any person appointed as LMKN Commissioner in the above manner does not have the legitimacy to claim itself as representative of a representation element. In the absence of the LMKN Commissioners' legitimacy to claim themselves as representatives of representation elements, the population of each representation element can deem the appointment of said LMKN Commissioners as being noncompliant with the rules set out in the Permenkumham.

In fact, said legal issue related to the appointment of LMKN Commissioners could have been avoided with an accurate formulation of the requirements for LMKN Commissioners by the Minister of Law and Human rights. If the Minister of Law and Human Rights intended to appoint people capable of acting independently, possessing the knowledge or experience required for the tasks and functions of LMKN Commissioners, the word "merepresentasikan" (representing) should not have been included in the definition article mentioned above.

Based on that notion, the organizational form of LMKN should be similar to LMK's organizational form, and that it must comply with the requirements set forth in the Copyright Law and Permenkumham for LMKs, namely as follows: 
a. Possessing an operational license

b. Meeting requirements as an LMK:

i. incorporated in the form of a non-profit Indonesian legal entity;

ii. having obtained powers from Authors, Copyright Holders, or Related Rights owners to draw, collect, and distribute Royalty;

iii. possess power granting members of at least 200 (two hundred) Authors for LMKs in the area of songs and/or music representing the interests of authors and not less than 50 (fifty) persons for LMKs representing the interests of Related Rights owners and/or other copyright objects;

iv. having the purpose of drawing, collecting and distribution Royalty; and

v. Possessing the capacity to draw, collect and distribute Royalty to Authors, Copyright Holders, or Related Rights owners.

In this case, as LMK, the LMKN must be incorporated as an Indonesian non-profit legal entity.

In Indonesia, entities with characteristics of a non-profit legal entity are Yayasan (Foundation) and Perkumpulan (Association). If the LMKN is in the form of a Yayasan, the organizational structure of Yayasan is applicable, with the Yayasan consisting of the following: Pembina (Trustees), Pengurus (Managers), and Pengawas (Supervisors). With due observance of the LMKN's organizational elements set forth in the new Copyright Law and in the Permenkumham, the LMKN being formed as a Yayasan, the organs of such Yayasan (Trustees, Managers, as well as Supervisors) must be elected from among or must represent elements of the LMKs concerned, authors'/related right owners, academicians, and Copyright law experts.

Another choice of non-profit legal entity is Perkumpulan (Association). Perkumpulan refers to Staatsblad 1870 No. 64 concerning Associations in the Form of Legal Entity (Rechtspersoonlijkheid van vereenigingen). The organizational structure, the main functions and authorities of each organ, as well as other matters related to Perkumpulan are provided for in a Statute. As stated in Article 2 of the Staatblaad 1870 No. 64: "Pengakuan dilakukan dengan menyetujui statuta atau reglemen-reglemen perkumpulan. Statuta atau reglemen berisi tujuan, dasar-dasar, lingkungan kerja dan ketentuan-ketentuan lain perkumpulan." [Unofficial translation: "Recognition is achieved by approving the statute or rules of association. The statute or rules include the purpose, the basis, working environment and other provisions concerning the association."]

Compared to the organizational aspect of the CISAC as a confederation of LMKs on an international level, another organizational form for the LMKN, in the context of Indonesian law, is Confederation or Federation. According to Kamus Besar Bahasa Indonesia, federasi (federation) is "consolidation of several organizations working together as one and the same body, however, each of them standing on their own," while konfederasi (confederation) (in the context of organization) is the "consolidation of several organizations, such as for instance labor organizations."

As the LMKN must be incorporated as a legal entity, the LMKN may very well take on the organizational form of federasi or konfederasi, whereby LMKs associated in it still stand on their own; however, organizationally they are consolidated and form the LMKN's organs or management. Given such organizational form, the decision making process can take place through the mechanism of member meetings, or general 
assembly (as is the case with the CISAC), with other supplementary organs such as Chairperson-Vice Chairperson or Board of Directors as the management, Supervisory Board and Secretariat, as well as other bureaus as required, appointed through the above mentioned members' meeting.

\section{CONCLUSION}

Based on the findings, the conclusions of this research are as follows:

a. the existing LMKs are likely not yet satisfied with the LMKN regulation and the composition of LMKN personnels;

b. the regulation on the LMKN and its relationship with the LMKs in Indonesia is unique and share no similarity with regulations in other countries;

c. the LMKN will not be easy to implement the rules concerning royalty collection and distribution, because they do not have full support from LMKs;

d. the most adequate LMKN and LMK regulation in Indonesia are as follows:

i. if the LMKN is to take the role as regulator, executor, supervisor, as well as mediator then a single type of organ such as the Commissioners shall not suffice. There is a need for a forum or an organ for making decisions and determining policy, for an organ to execute the collecting and distribution of royalties, for a supervisory organ, and for an organ to act as mediator. As an LMK on a national level, it would be only appropriate for the LMKN to be formed from LMKs, or to be a consolidation/association of LMKs in Indonesia;

ii. further provisions concerning the LMKN's tasks and authorities as well as the mechanism for implementing its tasks and authorities need to be improved. In order to be able to collect royalty, the LMKN needs to obtain powers from right holders, or it needs to obtain substitution powers from LMKs. This cannot be achieved without coordination with LMKs which already hold such powers. For instance, by granting substitution powers, or appointing LMK representatives as chairperson or members of the management board implementing the task of collecting and distributing royalties;

iii. the above mentioned LMKN provisions can be improved or adjusted by formulating a Government Regulation concerning LMKN, or by amending/supplementing the existing Regulation of the Minister of Law and Human Rights;

iv. on an organizational level, the LMKN appears to demonstrate the spirit of being the holder of public authority. There is a need to restore the LMKN to the original purpose of its formation, namely to implement a single door system. Accordingly, the LMKN needs to be restored to its original purpose, namely as an LMK. Its members should be the representation of LMKs, supplemented with members consisting of copyright law experts and financial management experts. Based on the foregoing, the following recommendations are being put forward concerning the organizational aspect of collecting music royalties in Indonesia; 
v. adjust the LMKN's organization in order to be in harmony with UUHC 2014 which reaffirms that the LMKN is an LMK, and therefore all regulations concerning LMK are applicable mutatis mutandis to the LMKN. In the initial stage, all existing LMKN Commissioners should remain in their position; however, elements of LMK need to be added subsequently to the LMKN;

vi. the Minister of Law and Human Rights needs to assume the role as umpire for the purpose of materializing a system for collecting and distributing royalties from works of music in a manner that achieves the intended target, and which is fair as well as accountable. In order to achieve this objective, the following three aspects need to be determined by the Minister of Law and Human Rights, namely: the aspects of regulation, organization and supervision respectively;

vii. in the aspect of regulation, the Minister of Law and Human Rights is the holder of administrative authority in the organization of collecting and distributing royalties in the music industry. Accordingly, it should be the Minister of Law and Human Rights setting forth regulations related to collecting and distributing royalties, supervising LMKs and the LMKN in matters related to collecting and distributing royalties. To date, the regulatory function has been implemented by the respective LMKs (as self regulatory bodies), as a result of which the regulations produced a lack of uniformity and as such tend to pose a burden on the commercial users of works of music;

viii. in the author's view, the Minister of Law and Human Rights can stipulate the LMKN as LMK implementing the single door system. The LMKN has the position of an organization which integrates LMKs and which has a legal relation only with the LMKs through substitution powers; hence, the LMKN does not need to check whether powers have been granted by Authors or Related Rights Owners directly. Considering that the LMKs already exist as self regulatory bodies, the significance of their position within the LMKN needs to be reaffirmed. For such purpose, the LMKN needs to be stipulated as a "non-profit legal entity in the form of a Federation". In the federation form, all LMKs existing prior to the formation of the LMKN can continue to exist individually and, at the same time, can put their representatives in the LMKN's management. The LMKN could learn from CISAC's experience as reference in determining the LMKN's management.

ix. the supervisory organ is needed in order to anticipate potential violations of the law. The Minister of Law and Human Rights needs to look out for administrative violations. In the event of criminal violations of the law, there is no need for a special procedural law for the aspect of collecting royalties. At the same time, for civil disputes, the burden of settlement should give priority to the initiative of the disputing parties. There are a lot of choices available for dispute settlement forum; hence, there is no need for intervention on the part of the Minister of Law and Human Rights for such civil aspect. Focus by the Minister of Law and Human Rights on the supervisory 
aspect related to administrative compliance is rather significant, because based on Copyright Law 28/2014, the LMK can only operate if it has obtained a permit from the Minister of Law and Human Rights. In such context, the Minister of Law and Human Rights has two options. First, assign the Public Official within its organizational structure to conduct supervision. The advantage of the said option is that the area of supervision is automatically brought to the national scale, due to the fact that the position of public officials within the organizational structure of the Ministry of Law and Human Rights is spread through regions. The disadvantage, however, is that the human resource available are likely to lack competence for implementing the task of supervision, because most of them do not fully understand the various aspects of intellectual property rights, in particular copyright. Second, form a non-structural organization. The weakness of this option is that the organization's personnel are not be able to be present in all regions immediately. However, it can be overcome by using electronic system facilities, for instance building website or establishing short text message (sms) centers for the purpose of receiving reports or complaints. The advantage of this option is that the Minister of Law and Human Rights can appoint people who possess the required competency, even though they may originate from non-state apparatus elements. Academicians, author practitioners, related rights practitioners, or other professionals would be eligible for appointment for a specific period of time to implement supervisory tasks. The author views that the Minister of Law and Human Rights needs to set up a non-structural organization, in the form of a Supervisory Commission, to implement the task of supervising the LMKN and the LMKs. 


\section{Bibliography}

\section{Legal Documents}

Indonesia. Undang-Undang tentang Hak Cipta (Law concerning Copyright), UU No. 28 tahun 2014, LN No. 266 tahun 2014 (Law No. 28 of 2014, SG No. 266 of 2014).

Undang-Undang tentang Yayasan (Law concerning Foundations), UU No. 16 tahun 2001 sebagaimana telah diubah dengan UU No. 28 tahun 2004 (Law No. 16 of 2001 as amended by Law No. 28 of 2014).

Minister of Law and Human Rights of Republic Indonesia, Peraturan tentang Tata Cara Permohonan dan Penerbitan Izin Operasional serta Evaluasi Lembaga Manajemen Kolektif [Regulation concerning the Application Procedure and Issuance of Operational Permint as well as the Evaluation of Collective Management Organization], Peraturan Nomor 29 tahun 2014 (Regulation No. 29 of 2014).

Staatsblad 1870 No. 64 tentang Perkumpulan-Perkumpulan Berbadan Hukum (Rechtspersoonlijkheid van vereenigingen) (Staatsblad 1870 No. 64 concerning Associations Incorporated as Legal Entities).

\section{Books}

Gervais, Daniel, ed. Collective Management of Copyright and Realted Rights. The Netherlands: Kluwer Law International, 2010.

Gomulkiewicz, et. al. Licensing Intellectual Property, Law and Application. Wolters Kluwer Law and Business, 2011.

Hugenholtz, P. Bernt. ed. The Future of Copyright in a Digital Environment. The Hague: Kluwer Law International, 1996.

Patry, William. How to Fix Copyright. New York: Oxford University Press, 2011.

Torremans, Paul. Copyright Law, A Handbook of Contemporary Research. Cheltenham, UK: Edward Elgar Publishing, Inc, 2007.

Wikstrom, Patrik. The Music Industry, Digital Media and Society Series. Cambridge: Polity, 2009.

\section{Articles}

Sardjono, Agus. "Problem Hukum Undang-Undang Hak Cipta 2014 dalam Pengaturan LMK dan LMKN [Issues of Law Related to the 2014 Copyright Law in Regulating LMK \& LMKN]", (paper presented in the seminar organized by PAPPRI, on November 25, 2014).

\section{Internet}

CISAC, "CISAC: Who We Are," retrieved from www.cisac.org/Who-We-Are, accessed 14 May 2016.

DetikHot,. "Rhoma Irama: Artis Dangdut Keluar Dari KCI [Rhoma Irama: Dangdut musicians exit KCI]," http://hot.detik.com/music/read/2013/03/28 
1113828/2206000/228/rhoma-irama-artis-dangdut-keluar-dari-kci,. aAccessed on 15 May 2016.

HukumOnline,. "Memungut Royalti Lagu, Hak Siapa? [Levying Music Royalty, Whose Right?]," $\quad$ http://www.hukumonline.com/berita/baca/hol15903/ memungut-royalti-lagu-hak-siapa,. aAccessed on 13 May 2016.

HukumOnline,. "Pro Kontra Eksistensi Lembaga Manajemen Kolektif [Pros and Cons of the Existence of Collective Management Organization]," http:// www.hukumonline.com/berita/baca/lt517fd780019e8/pro-kontraeksistensi-lembaga-manajemen-kolektif. A, accessed on 15 May 2016.

JASRAC,. "Entrustment of Copyright to JASRAC,." http://www.jasrac.or.jp/ejhp/ about/admini env.html. A, accessed on 14 May 2016.

Joglosemar,. "PHRI Solo Tolak Bayar Royalti KCI [Solo branch of Indonesian Association of Hotel and Restaurant refuse ot pay royalty for KCI]," http://www. edisicetak.joglosemar.co/node/20653. A, accessed on 16 May 2016.

Majalah Internet,. "Inul Daratista Minta Revisi UU Hak Cipta [Inul Daratista Request Copyright Law Revision],." http://www.majalahinternet.com/2013/04/ inul-daratista-minta-revisi-uu-hak-cipta.html. A, accessed on 13 May 2016.

Ministry of Law and Human Rights,. "Menkumham Melantik Komisioner LMKN Pencipta dan Hak Terkait [Minister of Law inaugurates Authors and Related Rights LMKN Commissioners]," http://www.kemenkumham. go.id/v2/berita/330-menkumham-melantik-komisioner-lmknpencipta-dan-lkmn-hak-terkait\#sthash.Sf9xa3w2.dpuf, accessed on 15 May 2016.

Tempo,. "Potensi Kerugian Hak Cipta Rp 3 Triliun per Tahun [Potential losses of copyright Reach 3 trillion rupiah annualy]," http://www.tempo.co/ read/news/2015/01/20/078636265/Potensi-Kerugian-Hak-Cipta-Rp3-Triliun-per-Tahun. A, accessed on 14 May 2016.

The International Confederation of Authors and Composers Societies. "CISAC: Who We Are." www.cisac.org/Who-We-Are. Accessed 14 May 2016.

Varia.id,. "LMKN Ingin Amankan Rp. 3 Triliun Royalti Lagu [LMKN wants to secure 3 trillion rupiah worth of music royalty," http://www. varia.id/2015/01/21/lmkn-ingin-amankan-rp-3-triliun-royaltilagu/\#ixzz3TL6Ps05n. A, accessed on 14 April 2016.

Vitri Angreni,. "Bens Leo: Bens Leo: Tugas LMKN Jangan Tumpang Tindih Dengan Lembaga Serupa [Bens Leo: Tasks of LMKN must not overlap with similar institutions]," $\quad$ http://www.portalkbr.com/berita/ perbincangan/3380210 5534.html. A, accessed 10 May 2016. 
